\title{
A New Flavanone with Antifungal Activity Isolated from $\mathrm{Hops}^{\dagger}$
}

\author{
Shigeyuki Mizobuchi and Yuko Sato \\ Applied Bioscience Laboratory, Kirin Brewery Co., Ltd, \\ 3-Miyahara, Takasaki, Gunma 370-12, Japan
}

Received May 23, 1984

\begin{abstract}
6-Isopentenylnaringenin 1, which has previously been synthesized by other workers, was isolated together with xanthohumol $\mathbf{2}$ and isoxanthohumol $\mathbf{3}$ from hard resins of hops (Humulus lupulus $\mathrm{L}$.). The structures of $\mathbf{1}$ and sophoraflavanone B were examined; that of the latter previously reported as 6-isopentenylnaringenin, has been revised to 8-isopentenylnaringenin. 1, $\mathbf{2}$ and $\mathbf{3}$ were found to have antifungal activities.
\end{abstract}

During a study of the antimicrobial activities of bitter resins of hops (Humulus lupulus L.) and related compounds, we found that constituents of hard resins of hops inhibited the growth of Trichophyton spp., pathogenic fungi in humans, and other microorganisms.

This paper reports the structural elucidation of $\mathbf{1}$ isolated from the hard resins of hops, and gives a revised structure for sophoraflavanone B. ${ }^{1)}$ The antifungal activities of $\mathbf{1}$ and related compounds are also discussed.

\section{MATERIALS AND METHODS}

All melting points are given as uncorrected values. UV spectra were determined by a Hitachi 624 spectrometer. ${ }^{1} \mathrm{H}$-NMR spectra were recorded on a JEOL FX-100 spectrometer at $100 \mathrm{MHz}$ with tetramethylsilane as an internal standard. Most ${ }^{13} \mathrm{C}-\mathrm{NMR}$ spectra were recorded on a JEOL FX-100 at $25 \mathrm{MHz}$, and some ${ }^{13} \mathrm{C}-\mathrm{NMR}$ spectra were recorded on a JEOL JX-400 spectrometer at $100 \mathrm{MHz}$ in the same way. Mass spectra were obtained with a Hitachi M-80 spectrometer (direct inlet system). The optical rotations were determined with a JASCO DIP140 polarimeter. Thin-layer chromatography (TLC) was carried out on Merck silica gel plates (art. 5731).

The minimum inhibitory concentrations of each compound were determined by the dilution method using nutrient agar medium. For fungi, a medium consisting of $1 \%$ peptone, $4 \%$ glucose and $1.5 \%$ agar was used, and the cultures were incubated at $27^{\circ} \mathrm{C}$ for 7 days. For bacteria, the medium consisted of $1 \%$ peptone, $0.7 \%$ meat extract,
$0.3 \% \mathrm{NaCl}$ and $1.5 \%$ agar, and the cultures were incubated at $37^{\circ} \mathrm{C}$ for $20 \mathrm{hr}$. The organisms tested are listed in Table I.

1. Isolation of xanthohumol 2 and isoxanthohumol $\mathbf{3}$. Hard resins $(8 \mathrm{~g})$, prepared from Saaz hops $(700 \mathrm{~g})$, were chromatographed on Dowex 1-X4 (AcOH form). After the column had been eluted with $80 \% \mathrm{MeOH}$, the fractions which were eluted with $1 \% \mathrm{AcOH}$ in $80 \% \mathrm{MeOH}$ and $5 \% \mathrm{AcOH}$ in $80 \% \mathrm{MeOH}$ were evaporated to obtain a brown solid $(195 \mathrm{mg})$ and a yellow solid $(1.8 \mathrm{~g})$, respectively. The yellow solid was washed with cold ether $(50 \mathrm{ml})$ to obtain a pale yellow powder $(550 \mathrm{mg})$. The washing solutions were combined and evaporated to obtain a crude product which was recrystallized from aqueous acetic acid to give $2(630 \mathrm{mg})$ as yellow crystals: $\mathrm{mp} 171 \sim 172.5^{\circ} \mathrm{C}$ (lit., ${ }^{2,3)} 171^{\circ} \mathrm{C}$ ).

The pale yellow powder $(550 \mathrm{mg})$ was recrystallized from aqueous acetic acid to give $3(340 \mathrm{mg})$ as colorless prisms: mp $197.5 \sim 198^{\circ} \mathrm{C}$ (lit., ${ }^{2,3)} 197 \sim 198^{\circ} \mathrm{C}$ ).

2. Isolation of $\mathbf{1}$ from hard resins of hops. The brown solid $(195 \mathrm{mg})$ mentioned above was dissolved in ether $(100 \mathrm{ml})$ and extracted with aqueous $10 \% \mathrm{Na}_{2} \mathrm{CO}_{3}(3 \times$ $30 \mathrm{ml}$ ). The extract was acidified with $1 \mathrm{~N} \mathrm{HCl}$ and reextracted with ether $(100 \mathrm{ml})$. The ether layer was washed with water, dried over $\mathrm{Na}_{2} \mathrm{SO}_{4}$ and concentrated to about $50 \mathrm{ml}$. Hexane was added to the concentrate at $0^{\circ} \mathrm{C}$ to obtain $1(19 \mathrm{mg})$ as colorless crystals: $\mathrm{mp} 209 \sim 209.5^{\circ} \mathrm{C}$ (recrystallized from ether-hexane); $[\alpha]_{\mathrm{D}}^{23}=0^{\circ} \quad(c=0.1$, $\mathrm{MeOH}) ; \mathrm{MS} m / z: 340\left(\mathrm{M}^{+}, 85 \%\right), 297$ (20), 285 (15), 220 (20), 205 (45), 192 (32), 177 (22), 165 (100), 120 (26); IR $\gamma_{\max }^{\mathrm{KBr}} \mathrm{cm}^{-1}: 3250(\mathrm{OH}), 1630(\mathrm{C}=0), 1585,1520$ (arom. $\mathrm{C}=\mathrm{C})$; UV $\lambda_{\max }^{\mathrm{MeOH}} \mathrm{nm}(\varepsilon): 294(17,700) ; \lambda_{\max }^{\mathrm{MeOH}+\mathrm{NaOH}} \mathrm{nm}$ : 332; $\lambda_{\max }^{\mathrm{MeOH}+\mathrm{AlCl}_{3}} \mathrm{~nm}: 315 ; \lambda_{\max }^{\mathrm{MeOH}+\mathrm{AlCl}_{3}+\mathrm{HCl}} \mathrm{nm}: 313 ;$

$\dagger$ This work was presented at the Annual Meeting of the Agricultural Chemical society of Japan, Tokyo, April 1984. 
$\lambda_{\max }^{\mathrm{MeOH}+\mathrm{AcONa}} \quad \mathrm{nm}: \quad 330 ; \quad \lambda_{\max }^{\mathrm{MeOH}+\mathrm{AcONa}+\mathrm{H}_{3} \mathrm{BO}_{3}} \quad \mathrm{~nm}: \quad 292 ;$ $\lambda_{\max }^{\mathrm{MeOH}+\mathrm{MeONa}} \mathrm{nm}: 332 ;{ }^{1} \mathrm{H}-\mathrm{NMR} \delta$ (acetone- $\left.d_{6}\right): 1.65,1.76$ (each $\left.3 \mathrm{H}, 2 \mathrm{~s},=\mathrm{C}\left(\mathrm{CH}_{3}\right)_{2}\right), 2.71(1 \mathrm{H}, \mathrm{dd}, J=17.1,3.4 \mathrm{~Hz}, 3-$ Ha), $3.20(1 \mathrm{H}, \mathrm{dd}, J=17.1,12.7 \mathrm{~Hz}, 3-\mathrm{Hb}), 3.24(2 \mathrm{H}, \mathrm{d}$, $\left.J=8.0 \mathrm{~Hz}, \mathrm{Ar}-\mathrm{CH}_{2}\right), 5.24(1 \mathrm{H}$, br.t, $J=8.0 \mathrm{~Hz},=\mathrm{CH})$, $5.40(1 \mathrm{H}, \mathrm{dd}, J=12.7,3.4 \mathrm{~Hz}, 2-\mathrm{H}), 6.03(1 \mathrm{H}, \mathrm{s}, 8-\mathrm{H}), 6.90$ $\left(2 \mathrm{H}, \mathrm{d}, J=8.8 \mathrm{~Hz}, 3^{\prime}-\right.$ and $\left.5^{\prime}-\mathrm{H}\right), 7.39\left(2 \mathrm{H}, \mathrm{d}, J=8.8 \mathrm{~Hz}, 2^{\prime}-\right.$ and $\left.6^{\prime}-\mathrm{H}\right), 8.50,9.54(2 \mathrm{H}, 2 \mathrm{~s}, \mathrm{OH} \times 2), 12.47(1 \mathrm{H}, \mathrm{s}, 5-\mathrm{OH})$; $\delta\left(\mathrm{CDCl}_{3}\right): 1.77,1.84\left(\right.$ each $\left.3 \mathrm{H}, 2 \mathrm{~s},=\mathrm{C}\left(\mathrm{CH}_{3}\right)_{2}\right), 2.76(1 \mathrm{H}$, dd, 3-Ha), 3.09 (1H, dd, 3-Hb), $3.35\left(2 \mathrm{H}, \mathrm{d}, \mathrm{Ar}-\mathrm{CH}_{2}\right), 5.25$ $(1 \mathrm{H}$, br.t, = $\mathrm{CH}), 5.33(1 \mathrm{H}, \mathrm{dd}, 2-\mathrm{H}), 6.00(1 \mathrm{H}, \mathrm{s}, 8-\mathrm{H})$, $6.87\left(2 \mathrm{H}, \mathrm{d}, 3^{\prime}-\right.$ and $\left.5^{\prime}-\mathrm{H}\right), 7.33\left(2 \mathrm{H}, \mathrm{d}, 2^{\prime}-\right.$ and $\left.6^{\prime}-\mathrm{H}\right), 12.39$ $(1 \mathrm{H}, \mathrm{s}, 5-\mathrm{OH}) ;{ }^{13} \mathrm{C}-\mathrm{NMR} \delta$ (DMSO-d $\left.{ }_{6}\right): 17.5$ (q, 14-C), 20.6 (t, 11-C), 25.4 (q, 15-C), 42.1 (t, 3-C), 78.4 (d, 2-C), 94.5 (d, 8-C), 101.7 (s, 10-C), 107.7 (s, 6-C), 115.3 (d, 3'and $\left.5^{\prime}-\mathrm{C}\right), 122.8(\mathrm{~d}, 12-\mathrm{C}), 128.2\left(\mathrm{~d}, 2^{\prime}-\right.$ and $\left.6^{\prime}-\mathrm{C}\right), 129.2(\mathrm{~s}$, $1^{\prime}-\mathrm{C}$ ), 130.2 (s, 13-C), 157.9 (s, 4'-C), 160.7 (s, 5- and 9-C), 164.4 (s, 7-C), 196.5 (s, 4-C); ${ }^{13} \mathrm{C}-\mathrm{NMR} \delta$ (DMSO-d ${ }_{6}$, proton coupled): 94.5 (d, $J=161.5 \mathrm{~Hz}, 8-\mathrm{C}), 101.7$ (br.t, $J=4.5 \mathrm{~Hz}, 10-\mathrm{C}$ ), 107.7 (br.t, $J=4.5 \mathrm{~Hz}, 6-\mathrm{C}$ ); ${ }^{13} \mathrm{C}-\mathrm{NMR} \delta$ (DMSO- $d_{6}$, decoupled at the $5-\mathrm{OH}$ proton frequency): 94.5 (d, $J=161.5 \mathrm{~Hz}, 8-\mathrm{C}$ ), 101.7 (d, $J=4.5 \mathrm{~Hz}, 10-\mathrm{C}$ ), $107.7(\mathrm{~d}, J=4.5 \mathrm{~Hz}, 6-\mathrm{C}) ; R f=0.51\left(\mathrm{CHCl}_{3}-\mathrm{MeOH}=\right.$ 9:1); $R f=0.54$ (benzene-AcOEt $=1: 1$ ); blue-black with ferric chloride in EtOH.

3. Synthesis of $\mathbf{1}$ and sophoraflavanone B 4. A mixture of naringenin $(2.5 \mathrm{~g})$ and sodium methoxide $(540 \mathrm{ng})$ in methanol $(50 \mathrm{ml})$ and ether $(100 \mathrm{ml})$ was treated with isopentenyl bromide $(1.7 \mathrm{~g})$ in the usual way. The reaction mixture was concentrated to dryness, and extracted with cold ether. The ether extract (about $1 \mathrm{~g}$ ) was chromatographed on Dowex 1-X4 in the same way as described in Section 1 to obtain compound B $(330 \mathrm{mg}$, from the fraction eluted with $0.5 \% \mathrm{AcOH} / 80 \% \mathrm{MeOH}$ ) and compound A $(210 \mathrm{mg}$, from the fraction eluted with $1 \%$ $\mathrm{AcOH} / 80 \% \mathrm{MeOH})$.

These compounds had the following characteristics. Compound B: mp $193 \sim 193.5^{\circ} \mathrm{C}$ (colorless crystals from aqueous methanol); MS m/z: $340\left(\mathrm{M}^{+}, 100 \%\right), 297$ (20), 285 (46), 220 (24), 205 (50), 192 (36), 177 (32), 165 (96), 120 (30); IR $\gamma_{\max }^{\mathrm{KBr}} \mathrm{cm}^{-1}: 3350(\mathrm{OH}), 1630(\mathrm{C}=\mathrm{O}), 1600,1520$ (arom. $\mathrm{C}=\mathrm{C}$ ); UV $\lambda_{\max }^{\mathrm{MeOH}} \mathrm{nm} \quad(\varepsilon): 295 \quad(18,100)$; $\lambda_{\max }^{\mathrm{MeOH}}+\mathrm{NaOH} \quad \mathrm{nm}: \quad 336 ; \lambda_{\max }^{\mathrm{MeOH}}+\mathrm{AlCl}_{3} \quad \mathrm{~nm}: 314$;

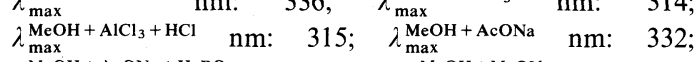
$\lambda_{\max }^{\mathrm{MeOH}+\mathrm{AcONa}+\mathrm{H}_{3} \mathrm{BO}_{3}} \mathrm{~nm}: \quad 291 ; \quad \lambda_{\max }^{\mathrm{MeOH}+\mathrm{MeONa}} \mathrm{nm}: 336$; ${ }^{1} \mathrm{H}-\mathrm{NMR} \delta$ (acetone- $\left.d_{6}\right): 1.60\left(6 \mathrm{H}, \mathrm{s},=\mathrm{C}\left(\mathrm{CH}_{3}\right)_{2}\right), 2.75$ $(1 \mathrm{H}, \mathrm{dd}, J=17.3,3.5 \mathrm{~Hz}, 3-\mathrm{Ha}), 3.15(1 \mathrm{H}, \mathrm{dd}, J=17.3$, $12.3 \mathrm{~Hz}, 3-\mathrm{Hb}), 3.22\left(2 \mathrm{H}, \mathrm{d}, J=8.3 \mathrm{~Hz}, \mathrm{Ar}-\mathrm{CH}_{2}\right), 5.19$ $(1 \mathrm{H}$, br. $\mathrm{t}, J=8.3 \mathrm{~Hz},=\mathrm{CH}), 5.43(1 \mathrm{H}, \mathrm{dd}, J=12.3$, $3.5 \mathrm{~Hz}, 2-\mathrm{H}), 6.02(1 \mathrm{H}, \mathrm{s}, 6-\mathrm{H}), 6.91(2 \mathrm{H}, \mathrm{d}, J=8.6 \mathrm{~Hz}$, $3^{\prime}-$ and $\left.5^{\prime}-\mathrm{H}\right), 7.42\left(2 \mathrm{H}, \mathrm{d}, J=8.6 \mathrm{~Hz}, 2^{\prime}-\right.$ and $\left.6^{\prime}-\mathrm{H}\right), 8.54$, $9.62(2 \mathrm{H}, 2 \mathrm{~s}, \mathrm{OH} \times 2), 12.14(1 \mathrm{H}, \mathrm{s}, 5-\mathrm{OH}) ; \delta\left(\mathrm{DCDl}_{3}\right)$ : $1.73\left(6 \mathrm{H}, \mathrm{s},=\mathrm{C}\left(\mathrm{CH}_{3}\right)_{2}\right), 2.78(1 \mathrm{H}, \mathrm{dd}, 3-\mathrm{Ha}), 3.07(1 \mathrm{H}$, $\mathrm{dd}, 3-\mathrm{Hb}), 3.31\left(2 \mathrm{H}, \mathrm{d}, \mathrm{Ar}-\mathrm{CH}_{2}\right), 5.21(1 \mathrm{H}$, br.t, $=\mathrm{CH})$, $5.36(1 \mathrm{H}, \mathrm{dd}, 2-\mathrm{H}), 6.03(1 \mathrm{H}, \mathrm{s}, 6-\mathrm{H}), 6.88\left(2 \mathrm{H}, \mathrm{d}, 3^{\prime}-\right.$ and $\left.5^{\prime}-\mathrm{H}\right), 7.34\left(2 \mathrm{H}, 2^{\prime}-\right.$ and $\left.6^{\prime}-\mathrm{H}\right), 11.99(1 \mathrm{H}, \mathrm{s}, 5-\mathrm{OH}) ;{ }^{13} \mathrm{C}-$
NMR $\delta$ (DMSO- $\left.d_{6}\right): 17.5$ (q, 14-C), $21.2(\mathrm{t}, 11-\mathrm{C})$, 25.4 (q, 15-C), 42.2 (t, 3-C), 78.2 (d, 2-C), 95.5 (d, 6-C), 101.9 (s, 10-C), 107.1 (s, 8-C), 115.3 (d, 3'- and 5'-C), 122.9 (d, 12-C), 128.0 (d, 2' - and 6'-C), 129.4 (s, 1'-C), 130.2 (d, 13-C), 157.7 (s, 4'-C), 159.9 (s, 9-C), 161.4 (s, 5-C), 164.5 (s, 7-C), 196.7 (s, 4-C); $R f=0.55\left(\mathrm{CHCl}_{3}-\mathrm{MeOH}=9: 1\right)$; $R f=0.59$ (benzene-AcOEt $=1: 1$ ); blue-black with ferric chloride in EtOH.

These analytical data were in good agreement with those of sophoraflavanone $\mathrm{B}^{1)}$ Compound A: The compound obtained in this way had the same characteristics as $\mathbf{1}$ isolated from hard resins of hops.

$\left[{ }^{13} \mathrm{C}-\mathrm{NMR} \delta\right.$ (DMSO- $d_{6}$ ) of naringenin 9: 41.9 (t, 3-C), 78.3 (d, 2-C), 94.9 (d, 8-C), 95.7 (d, 6-C), 101.8 (s, 10-C), $115.2\left(\mathrm{~d}, 3^{\prime}-\right.$ and $\left.5^{\prime}-\mathrm{C}\right), 128.1$ (d, 2' - and 6'-C), 128.9 (s, 1'C), $157.7\left(\mathrm{~s}, 4^{\prime}-\mathrm{C}\right), 162.9(\mathrm{~s}, 9-\mathrm{C}), 163.5(\mathrm{~s}, 5-\mathrm{C}), 166.7(\mathrm{~s}, 7-$ C), $196.3(\mathrm{~s}, 4-\mathrm{C})$; UV of naringenin 9: $\lambda_{\max }^{\mathrm{MeOH}} \mathrm{nm}(\varepsilon): 288$ $(16,500) \quad \lambda_{\max }^{\mathrm{MeOH}+\mathrm{NaOH}} \mathrm{nm}: 324 ; \lambda_{\max }^{\mathrm{MeOH}+\mathrm{AlCl}_{3}} \mathrm{~nm}: 311$; $\lambda \underset{\max }{\mathrm{MeOH}+\mathrm{AlCl}_{3}+\mathrm{HCl}} \quad \mathrm{nm}: \quad 310 ; \quad \lambda_{\max }^{\mathrm{MeOH}+\mathrm{AcONa}} \mathrm{nm}: 323$; $\lambda \underset{\max }{\mathrm{MeOH}+\mathrm{AcONa}+\mathrm{H}_{3} \mathrm{BO}_{3}} \mathrm{~nm}: 289 ; \lambda_{\max }^{\mathrm{MeOH}+\mathrm{MeONa}} \mathrm{nm}: 324$.]

4. Preparation of dihydroisoxanthohumol 5. A mixture of isoxanthohumol $3(60 \mathrm{mg})$ and platinum oxide $(8 \mathrm{mg})$ in methanol $(30 \mathrm{ml})$ was treated in an atmosphere of hydrogen to obtain $5\left(51 \mathrm{mg}, \mathrm{mp} 176 \sim 177^{\circ} \mathrm{C}\right.$, colorless needles from aq. $\mathrm{MeOH}$ ).

5. Preparation of 6-isopentylnaringenin 6. Compound A $(30 \mathrm{mg})$ described in Section 3 was hydrogenated in the presence of platinum oxide $(6 \mathrm{mg})$ to obtain $6(26 \mathrm{mg}, \mathrm{mp}$ $223.5 \sim 224^{\circ} \mathrm{C}$, colorless crystals from aq. $\left.\mathrm{MeOH}\right)$. MS $m / z: 342\left(\mathrm{M}^{+}, 73 \%\right), 165(100)$; IR $\gamma_{\max }^{\mathrm{KBr}} \mathrm{cm}^{-1}: 3150(\mathrm{OH})$, $1630(\mathrm{C}=\mathrm{O}), 1590,1520$ arom. $\mathrm{C}=\mathrm{C})$; UV $\lambda_{\max }^{\mathrm{MeOH}} \mathrm{nm}(\varepsilon)$ : $294(17,800) ;{ }^{1} \mathrm{H}-\mathrm{NMR} \delta$ (acetone- $\left.d_{6}\right): 0.92(6 \mathrm{H}, \mathrm{d}, J=$ $\left.6.1 \mathrm{~Hz}, \mathrm{CH}_{3} \times 2\right), 1.24 \sim 1.80\left(3 \mathrm{H}, \mathrm{m},-\mathrm{CH}_{2}-\mathrm{CH}\right), 2.58$ $\left(2 \mathrm{H}, \mathrm{t}, J=7.5 \mathrm{~Hz}, \mathrm{Ar}-\mathrm{CH}_{2}\right)$.

6. Preparation of 8-isopentylnaringenin 7. Dihydroisoxanthohumol 5 (40 mg) was dissolved in dry nitrobenzene $(6 \mathrm{ml})$. Freshly powdered aluminum chloride $(30 \mathrm{mg}$ ) was then added in three portions and the mixture was kept at $90 \sim 100^{\circ} \mathrm{C}$ for $1.5 \mathrm{hr}$. The mixture was diluted with water $(50 \mathrm{ml})$, and the precipitated solid was chromatographed on Dowex 1-X4 in the same way as described in Section 1 to obtain $7(16 \mathrm{mg}$, from the fraction eluted with $0.5 \% \mathrm{AcOH} / 80 \% \mathrm{MeOH}$ ).

7 was also obtained by hydrogenation of compound B $(30 \mathrm{mg})$ in the presence of platinum oxide $(5 \mathrm{mg})$ as described in Section 4. The product was recrystallized from aqueous methanol to obtain $4(26 \mathrm{mg})$ as colorless flakes: $\mathrm{mp} 195.5 \sim 196^{\circ} \mathrm{C}$; MS $m / z: 342\left(\mathrm{M}^{+}, 84 \%\right), 165$ (100); IR $\gamma_{\max }^{\mathrm{KBr}} \mathrm{cm}^{-1}: 3300(\mathrm{OH}), 1630(\mathrm{C}=\mathrm{O}), 1600,1510$ (arom. C=C); UV $\lambda_{\max }^{\mathrm{MeOH}} \mathrm{nm}(\varepsilon): 294(17,100) ;{ }^{1} \mathrm{H}-\mathrm{NMR} \delta$ (acetone- $\left.d_{6}\right): 0.87\left(6 \mathrm{H}, \mathrm{d}, J=6.0 \mathrm{~Hz}, \mathrm{CH}_{3} \times 2\right), 1.20-1.75$ $\left(3 \mathrm{H}, \mathrm{m},-\mathrm{CH}_{2}-\mathrm{CH}\right), 2.56\left(2 \mathrm{H}, \mathrm{t}, J=7.5 \mathrm{~Hz}, \mathrm{Ar}-\mathrm{CH}_{2}\right)$.

7. Preparation of 8-isopentyl-5,7,4-trimethoxynarin- 
genin 8. A mixture of dihydroisoxanthohumol $5(45 \mathrm{mg})$, dimethyl sulfate $(0.05 \mathrm{ml})$ and anhydrous $\mathrm{K}_{2} \mathrm{CO}_{3}(0.5 \mathrm{~g})$ in acetone $(15 \mathrm{ml})$ was refluxed for $6 \mathrm{hr}$. The product was chromatographed on a silica gel TLC plate with a mixture of $\mathrm{CHCl}_{3}$-hexane $(1: 1)$ as the solvent, and a colorless band with no ferric reaction at $R f=0.2$ was extracted with chloroform and concentrated to obtain a white solid. The solid was recrystallized from aqueous methanol to obtain $8(11 \mathrm{mg})$ as colorless prisms: $\mathrm{mp} 95.5 \sim 96^{\circ} \mathrm{C}$; $\mathrm{MS} \mathrm{m} / z: 384$ $\left(\mathrm{M}^{+}, 51 \%\right), 193(100)$; IR $\gamma_{\max }^{\mathrm{CHCl}_{3}} \mathrm{~cm}^{-1}: 1660(\mathrm{C}=\mathrm{O}), 1600$, 1570,1510 (arom. C=C); UV $\lambda_{\max }^{\mathrm{MeOH}} \mathrm{nm}(\varepsilon): 288(17,100)$; ${ }^{1} \mathrm{H}-\mathrm{NMR} \delta\left(\mathrm{CDCl}_{3}\right): 0.88\left(6 \mathrm{H}, \mathrm{d}, J=6.0 \mathrm{~Hz}, \mathrm{CH}_{3} \times 2\right)$, 1.2-1.6 (3H, m, $\left.-\mathrm{CH}_{2}-\mathrm{CH}\right), 2.57\left(\mathrm{t}, J=7.6 \mathrm{~Hz}, \mathrm{Ar}-\mathrm{CH}_{2}\right)$, $2.78(1 \mathrm{H}, \mathrm{dd}, J=16.6,4.9 \mathrm{~Hz}, 3-\mathrm{Ha}), 3.00(1 \mathrm{H}, \mathrm{dd}, J=$ $16.6,11.03 \mathrm{~Hz}, 3-\mathrm{Hb}$ ), 3.83, 3.89, 3.93 (each $3 \mathrm{H}, 3 \mathrm{~s}$, $\left.\mathrm{OCH}_{3} \times 3\right), 5.33(1 \mathrm{H}, \mathrm{dd}, J=11.03,4.9 \mathrm{~Hz}, 2-\mathrm{H}), 6.12(1 \mathrm{H}$, s, 6-H), $6.93\left(2 \mathrm{H}, \mathrm{d}, J=8.8 \mathrm{~Hz}, 3^{\prime}-\right.$ and $\left.5^{\prime}-\mathrm{H}\right), 7.38(2 \mathrm{H}, \mathrm{d}$, $J=8.8 \mathrm{~Hz}, 2^{\prime}-$ and $\left.6^{\prime}-\mathrm{H}\right)$.

8 (13 mg) was also obtained by methylation of 8isopentylnaringenin $7(110 \mathrm{mg})$ with dimethyl sulfate $(0.1 \mathrm{ml})$ and anhydrous $\mathrm{K}_{2} \mathrm{CO}_{3}(1 \mathrm{~g})$ in acetone $(15 \mathrm{ml})$ in the same way.

\section{RESULTS AND DISCUSSION}

\section{Structure of $\mathbf{1}$ isolated from hard resins}

Compound 1 was obtained as colorless crystals (mp $209 \sim 209.5^{\circ} \mathrm{C}, \mathrm{M}^{+}=m / z$ 340). Its IR gave absorption bands for the hydroxyl, conjugated carbonyl and benzene groups. The ${ }^{1} \mathrm{H}$ NMR of 1 (acetone- $d_{6}$ ) revealed the presence of an isopentenyl group, the 2- and 3-proton of flavanone, four aromatic protons of 1', 4'disubstituted benzene, one aromatic proton $[\delta$
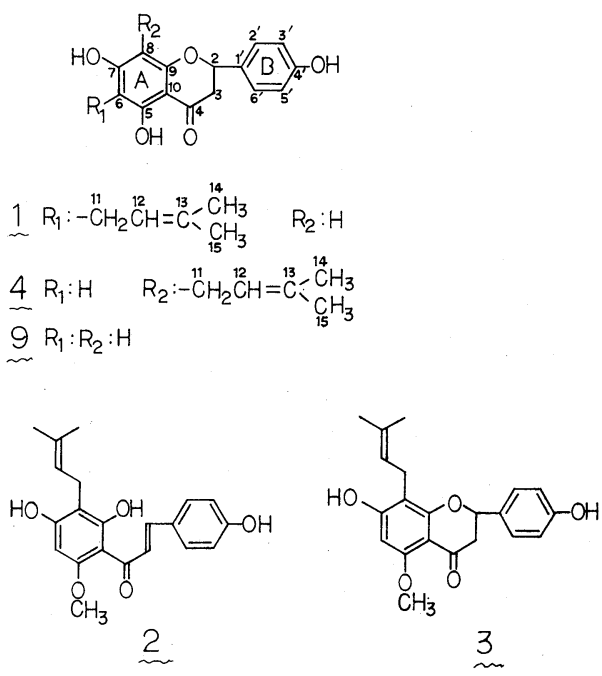

FIG. 1.
$6.03(1 \mathrm{H}, \mathrm{s})]$, and three hydroxyl protons, one being chelated at $\delta=12.47$. The MS of 1 showed fragments by the retro-Diels-Alder fragmentation of flavanone ${ }^{4)}$ at $m / z 220$ (Aring) and at $m / z 120$ (B-ring), suggesting the presence of an isopentenyl group on the Aring, and one hydroxyl group on the B-ring, respectively. The UV shifts of 1 after adding shifting reagents ${ }^{5)}$ suggested the presence of a naringenin $\left(5,7,4^{\prime}\right.$-trihydroxyflavanone) structure. The possibility of this naringenin structure is also supported by the appearance in the ${ }^{13} \mathrm{C}$-NMR spectrum of fifteen signals attributable to the carbons of naringenin.

These findings show that $\mathbf{1}$ is a naringenin derivative with one isopentenyl group at $6-\mathrm{C}$ or 8-C.

The position of the substituent was determined from the long-range decoupled ${ }^{13} \mathrm{C}$ NMR spectra of $\mathbf{1}$. Irradiation at the $5-\mathrm{OH}$ proton frequency changed two broad triplets at $\delta 101.7(J=4.5 \mathrm{~Hz}, 10-\mathrm{C})$ and $\delta 107.7(J=$ $4.5 \mathrm{~Hz}, 6-\mathrm{C})$ in the proton-coupled spectrum, respectively, into two doublets $(J=4.5 \mathrm{~Hz})$, but did not change the doublet at $\delta 94.5(J=$ 161.5 Hz, 8-C).

Wehrli' ${ }^{6)}$ has reported that the protoncoupled ${ }^{13} \mathrm{C}$-NMR spectra of naringenin exhibited spin-spin coupling between the 6-C and 10- $\mathrm{C}$ carbons and the chelated $5-\mathrm{OH}$ proton, but not between the $8-\mathrm{C}$ carbon and the $5-\mathrm{OH}$ proton, and thus permitting identification of these carbon atoms. Therefore, the structure of $\mathbf{1}$ is represented as 6-isopentenylnaringenin.

This is the same structure as that proposed for sophoraflavanone B by other workers. ${ }^{1)}$ However, the spectral data for sophoraflvanone $B$ were not identical with those for 1. Nevertheless, it is clear that the two compounds are structurally very similar, each having the same naringenin structure and isopentenyl group, as revealed by ${ }^{1} \mathrm{H}$ and ${ }^{13} \mathrm{C}$ NMR data. A possible difference between the two compounds is in the position of the isopentenyl group, and sophoraflavanone $\mathrm{B}$ is assumed to be an isomer of $\mathbf{1}$, that is, 8-isopentenylnaringenin 4.

6- and 8-isopentenylnaringenin have pre- 


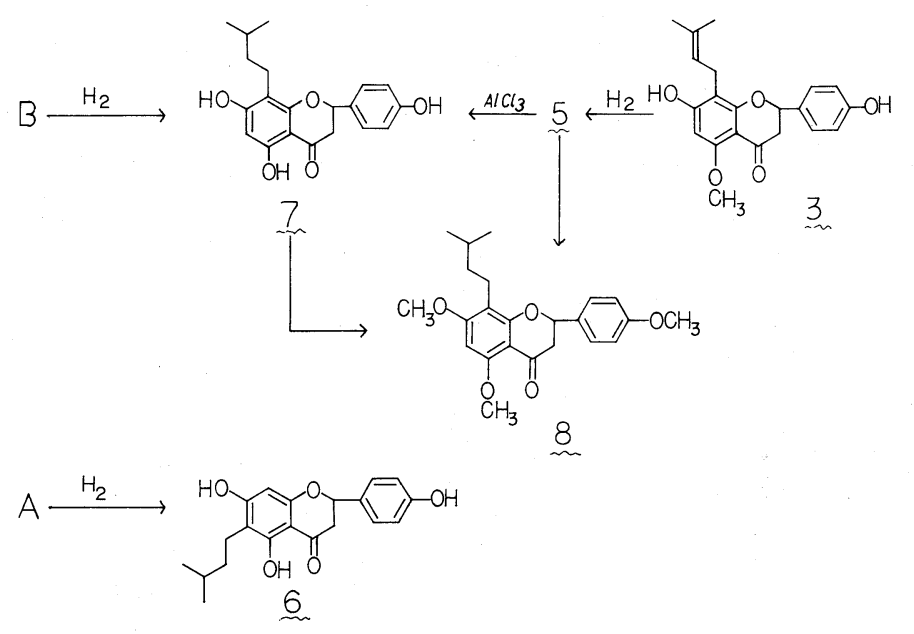

CHART 1.

viously been synthesized by Jain et al..$^{7,8)}$ and Nagar et al. ${ }^{9)}$ But their reported ${ }^{1} \mathrm{H}-\mathrm{NMR}$ data do not agree with each other. Moreover, ${ }^{1} \mathrm{H}$-chemical shifts in $\mathrm{CDCl}_{3}$ for 6-isopentenylnaringenin were reported to be the same as those in acetone- $d_{6},{ }^{7,8)}$ but ${ }^{1} \mathrm{H}$-chemical shifts in these two solvents are not the same according to our experiments. It is therefore impossible to identify 6- and 8-isopentenylnaringenin only by comparing the reported data.

To investigate the structure of sophoraflavanone $B$, naringenin was isopentenylated to give two monoisopentenylated compounds, A and $\mathrm{B}$. The melting point, mixed melting point and the spectral data for A were completely identical with those for $\mathbf{1}$ isolated from hops, and all the spectral data for $B$, except the specific rotation, were in good agreement with those for sophoraflavanone B. A direct comparison of the two compounds was carried out as follows:

As shown in Chart 1, isoxanthohumol 3 was hydrogenated in methanol over platinum oxide to give dihydroisoxanthohumol $\mathbf{5}$, which was then demethylated by aluminum chloride in nitrobenzene to give 8-isopentylnaringenin 7. The product so obtained from isoxanthohumol was found to be identical with the compound obtained by hydrogenation of $\mathrm{B}$ (=sophoraflavanone B), but not with the com- pound obtained by hydrogenation of A (= flavanone 1 isolated from hops).

No Wessely-Moser rearrangement occurred on demethylation of dihydroisoxanthohumol 5 with aluminum chloride, ${ }^{10,11)}$ because methylation of the demethylated product of dihydroisoxanthohumol and dihydroisoxanthohumol gave the same product, 8-isopentyl-5, 7, 4'-trimethoxynaringenin 8.

From these findings, the isopentenyl group of sophoraflavanone B (=compound B) is concluded to be attached at 8-C, and sophoraflavanone $\mathrm{B}$ is 8 -isopentenylnaringenin, as represented by 4 .

\section{Antifungal activities of constituents of hard} resins and related compound $1 \sim 4$ and 9

The antifungal activities of these compounds are shown in Table I in comparison with griseofulvin.

6-Isopentenylnaringenin 1 and xanthohumol 2 showed higher antifungal activities than griseofulvin against Trichophyton spp., and these compounds also showed slight activity against Mucor spp. However, isoxanthohumol 3 showed only slight activity against Trichophyton spp.

From a comparison of the activities of 6isopentenylnaringenin 1, isoxanthohumol 3, 8isopentenylnaringenin 4 and naringenin 9 , it is clear that the introduction of an isopentenyl 
Table I. Antifungal Activities of $1 \sim 4$ and 9

\begin{tabular}{lcccccc}
\hline & \multicolumn{5}{c}{ Minimum inhibitory concentrations $(\mu \mathrm{g} / \mathrm{ml})$} \\
\cline { 2 - 7 } \multicolumn{1}{c}{ Organisms tested } & $\mathbf{1}$ & $\mathbf{2}$ & $\mathbf{3}$ & $\mathbf{4}$ & $\mathbf{9}$ & Griseofulvin \\
\hline Trichophyton mentagrophytes & 3.13 & 3.13 & 200 & 6.25 & 200 & 6.25 \\
Trichophyton rubrum & 3.13 & 3.13 & $>200$ & 12.5 & $>200$ & 6.25 \\
Candida albicans & $>200$ & $>200$ & $>200$ & $>200$ & $>200$ & $>200$ \\
Fusarium oxysporum & $>200$ & $>200$ & $>200$ & 200 & $>200$ & $>200$ \\
Mucor rouxianus & 50 & 50 & $>200$ & 12.5 & 100 & $>200$ \\
Staphylococcus aureus & 6.25 & 6.25 & 50 & 25 & 100 & $>200$ \\
Escherichia coli & $>200$ & $>200$ & $>200$ & $>200$ & $>200$ & $>200$ \\
\hline
\end{tabular}

group into naringenin increases its antifungal activities against Trichophyton and Mucor spp., and the introduction of a methyl group into 5-OH significantly decreases the activity. Furthermore, 6-isopentenylnaringenin 1 was more active than 8-isopentenylnaringenin 4 against Trichophyton spp., but less active than the latter against Fusarium and Mucor spp. All compounds $1 \sim \mathbf{4}$ and 9 were active against Staphylococcus spp.

Acknowledgments. The authors wish to express their thanks to Kirin Co. for permission to publish this work, and Professor N. Otake and Associate Professor H. Seto, The University of Tokyo, for ${ }^{13} \mathrm{C}-\mathrm{NMR}$ measurements and helpful advice. They also thank Professor I. Yokoe and Dr. Y. Shirataki, Josai University, for spectral data on sophoraflavanone B, and Professor M. Nakajima, Kyoto University and Dr. K. Kitamura, Kirin Co., for encouragement.

\section{REFERENCES}

1) M. Komatu, I. Yokoe and Y. Shirataki, Chem. Pharm. Bull., 26, 3863 (1978).
2) M. Verzele, J. Stockx, F. Fontijn and M. Anteunis, Bull. Soc. Chim. Belges, 66, 452 (1957).

3) P. R. Ashurst, J. Laws and R. Stevens, J. Inst. Brew., 71, 492 (1965).

4) J. B. Harborne, T. J. Mabry and H. Mabry, "The Flavonoids," Chapman and Hall Ltd., London, 1975, pp. $78 \sim 126$.

5) T. J. Mabry, K. R. Markham and M. B. Thomas, "The Systematic Identification of Flavonoids," Springer-Verlag Ltd., New York, 1970, pp. 165 226; Y. Tomita, "Zoku Jikken Kagaku Koza," Vol. 5, ed. by the Chemical Society of Japan, Maruzen Co., Ltd., Tokyo, 1966, pp. 940 942.

6) F. W. Wehrli, J. Chem. Soc., Chem. Commun., 663 (1975).

7) A. C. Jain, R. C. Gupta and P. D. Sarpal, Tetrahedron, 34, 3563 (1978).

8) A. C. Jain, R. C. Gupta and P. D. Sarpal, Chem. Lett., 995 (1978).

9) A. Nagar, V. K. Gujral and S. R. Guputa, Tetrahedron Lett., 2031 (1978).

10) T. R. Seshadri, "The Chemistry of Flavonoid Compounds," ed. by T. A Geissman, Pergamon Press Inc., Oxford, 1962, p. 184.

11) R. C. Shah, C. R. Mehta and T. S. Wheeler, J. Chem. Soc., 38, 1555 (1938). 